\title{
膝蓋骨疾患に㧍けるCybex-II による膝伸展・屈曲力の検討
}

\author{
九州大学附属病院理学療法部 \\ 豊 永 敏 宏*・川 島 圭 司* \\ 九州厚生年金病院整形外科 \\ 上 崎 典 雄** \\ 九州大学整形外科 \\ 緒 方 公 介***
}

\section{A Study of the Knee Extensor and Flexer Muscle Strength in the Patellar Disease using Cybex-II}

by

\author{
T. Toyonaga, K. Kawashima, N. Uezaki \\ and K. Ogata \\ * Division of Physical Therapy, Faculty of Medicine, \\ Kyushu University. \\ ** Orthopedic Surgery, Kurosaki-Koseinenkin Hospital \\ *** Department of Orthopedic Surgery, Faculty of \\ Medicine, Kyushu University.
}

The authors have investigated the muscle strength about the knee with the patellofemoral joint problems (recurrent patellar dislocation; 6 cases, chondromalacia patellae ; 3 cases, subluxation of the patella; 3 cases, and others; 2 cases), comparing with intact group using Cybex-II. We have also observed the electromyogram of the thigh muscles. The results were as followes: (1) All patients showed significant decrease in the extensor muscle strength of the affectd limb postoperatively. (2) It was suggested that the muscle exercise was important both preoperatively and postoperatively to maintain satisfactory muscle strength about the knee.

は じめに

膝蓋骨は膝伸展機構 extensor apparatus のなか で最も重要な器官であり, 習慣性膝蓋骨脱臼や膝蓋骨 軟骨軟化症など膝蓋骨に起因する疾患においては，膝 蓋骨が膝伸展力におよぼす影響は多大であると思われ る.

しかしながら，乙れらの疾患の術前・術後における 筋力の定量的測定や筋動作学的研究は少ない(1)6).

従って, 著者らは等速運動性機器として多用されて いる Cybex machine を使用して, 膝蓋骨疾患の膝 伸展・届曲力を測定し対照群である正常人と比較検討 を行なった. また, 対象疾患の一部に, 大腿四頭筋や
表 1 対 象 症 例

\begin{tabular}{|c|c|c|c|c|c|}
\hline 症例 & 名 & 年令 & 性別 & $\begin{array}{l}\text { 手術側 } \\
\text { (患側) }\end{array}$ & $\begin{array}{c}\text { 筋電 } \\
\text { 図 }\end{array}$ \\
\hline & 習慣性膝蓋骨脱臼 & 16 & 女 & 右 & あり \\
\hline. $\mathrm{n}$ & " & 20 & 女 & 左 & 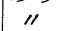 \\
\hline & "I & 18 & 女 & 両側 (術後) & "I \\
\hline [ & " & 18 & 女 & 右 (II) & " \\
\hline & " & 22 & 女 & 左 ( I & " \\
\hline 1. & "I & 14 & 鿖 & 左 & " \\
\hline $\mathrm{H}$. & 外佰性滕蓋骨脱臼 & 20 & 男 & 両側 C & " \\
\hline & 滕蓋骨軟骨軟化症 & 23 & 女 & 11 ( " & なし \\
\hline $\mathrm{K}$. & 祆莣，骨覀眖白 & 23 & 女 & $\begin{array}{l}\text { 右 (" } \\
\text { 左 ( I }\end{array}$ & $\begin{array}{l}\text { あり } \\
\text { な乞 }\end{array}$ \\
\hline & 的 & 30 & 女 & 右 & あり \\
\hline & " & 14 & 女 & 両側 (術前) & な乙 \\
\hline & 膝蓋骨骨折 & 42 & 女 & 左 (術後) & "I \\
\hline & 㯟蓋大腿関節症 & 62 & 男 & 右 ("I) & "I \\
\hline
\end{tabular}


半腱様筋などから表面筋電図を描出し，筋收縮の態様 あ併せて検討したので報告するる。

\section{対象と方法}

刘象症例は九大整形外科およびその関連病院で治療 を受けた 14 才から 62 才までの 14 症例である。術後 例 11 例 14 関節の術後観察期間は 6 力月より 9 年まで 平均 38 力月である（表 1)。また，乙れらと比較する ために九大病院職員の正常人と考元られる男女 80 名 の両膝関節筋力を対照として，以下の方法で測 定し た.

測定は Cybex-II (Lumex 社, 米国) を用い, dynamometer の回転数は 5 r.p.m.（1 分間に5 回 転)，筋トルク值の scale は $180 \mathrm{ft} .-1 \mathrm{bs}$ と一定に した．坐位にて両手は測定台の両横を把持させ，最大 努力の膝屈伸を数回行なわせ筋トルク曲線を描出した (図1)、測定の際に，苟らかじめコンピュータ一と連 結しておき, 即時にピークトルク值, 最大仕事量など 8 項目が算出できるようにし，得られた data の統計 処理を行なっだ)。なお，ピークトルク值とは，最大 筋力が出せるよう下肢長に応じて変化させたアームの 長さで割った値すなわちピークトルクとアームの比 （単位は ft.-lbs）とした。

次に筋力測定之同時に 4 チャンネルのテレメーター 式表面筋電計（日本光電）を使用し，大腿四頭筋の大 腿直筋抢よび内・外側広筋さらに対象の一部の半腱様 筋に表面電極を貼布し，表面筋電図を描出した。 な お，Cybex-II と筋電図の記録紙の送り速さは $5 \mathrm{~mm}$ / sec と一定にし同時計録を行なった（図 2 ).

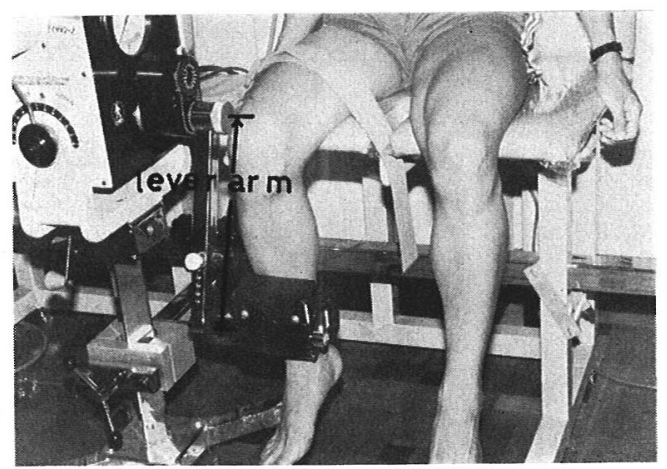

図 1 筋トルク值の測定 アームの長さは各々の下肢長に応してている。
症例

症例のうちなされた術式は, Tavernier 法 3 例 5 関節, 半腱様筋腱移行術 (上崎法 ${ }^{8}$ ) 2 例 2 関節, Maquet 法 3 例 4 関節，その他 3 関節である.

症例 1.M.T., 16 才，女子。主訴：右膝関節痛. 12 才頃より特々右摩関節が急に曲がり転倒していた. 単純 $\mathrm{X}$ 線像では，膝蓋骨亚脱且位にある健側に対して 患側は脱其位となっている(図 3 a， b). 筋力测定の際 飞検者が滕蓋骨を保持し，脱臼しないようにすると筋 力は出現するが，脱㕵時は検出不能であった（図 3 c，d）。また，筋電図では脱毛時に，内側広筋は筋収 縮が保たれていた（図３ｅ，f）。

症例 2.A.F., 22 才，女子，10才時より左膝盖骨が 外側飞脱臼を繰り返すので，13才時に半腱様筋腱移行 術を施行後，現在日常生活には支障をきたしていな い，X線像では健側の亜脱其位はあるが，患側の膝蓋 骨の外方偏位は健側に比べて高度である（図 $4 \mathrm{a}, \mathrm{b}$ ). 筇トルク曲線は健側と相違し伸展時の後半にピークを 示す特徽的なもの之なっている（図 $4 \mathrm{c} ， \mathrm{~d}$ )。筋電図 の半腱様筇で, 伸展時に陽性とならない筋収縮がみら れ，屈曲時にはさらに強い収縮が出現した（図 $4 \mathrm{e}$, f).

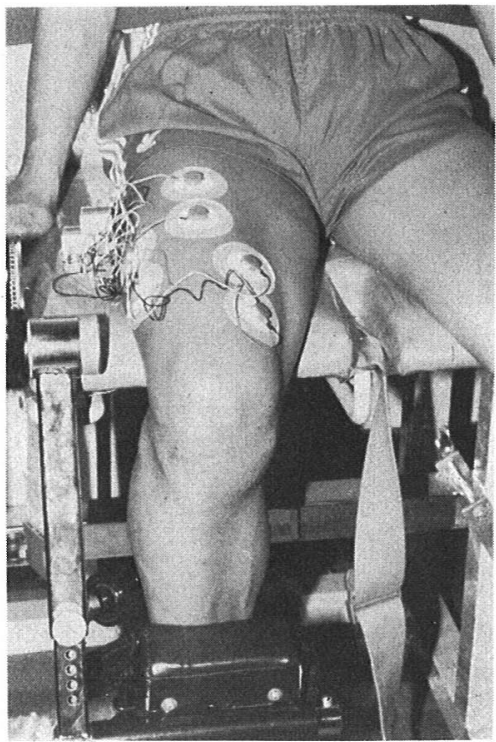

図 2 表面筋電図の抽出

大腿直笳抢よび内・外側広筋飞電極が貼布されて いる. 


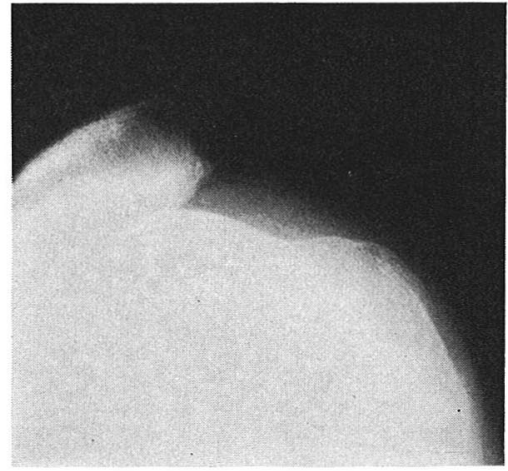

a
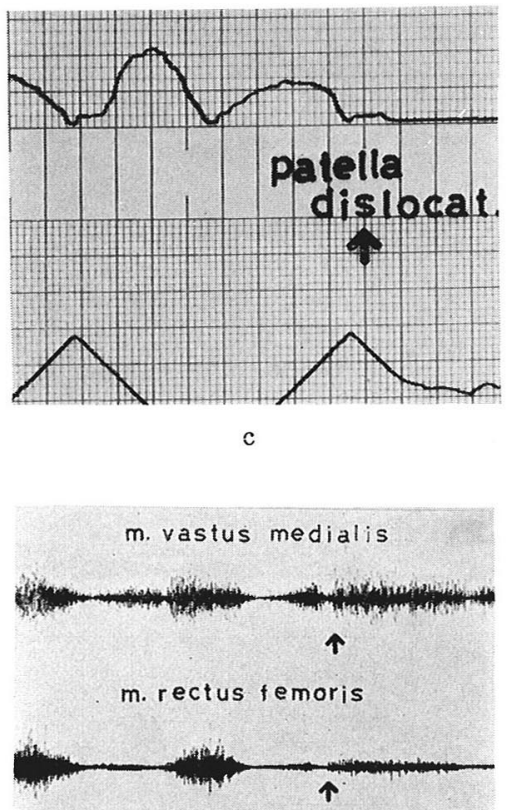

m. vastus lateralis

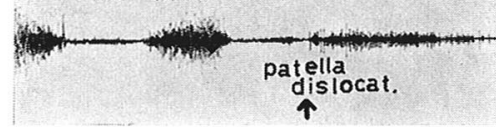

e

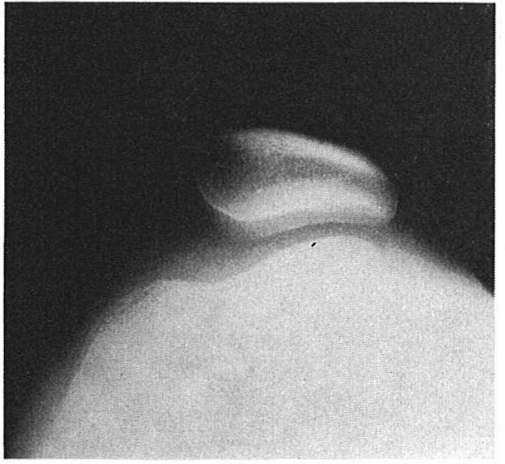

b

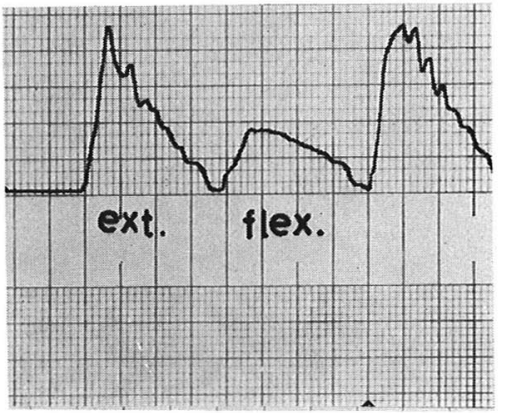

d

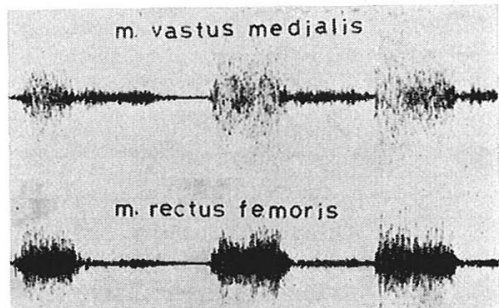

m. vastus lateralis

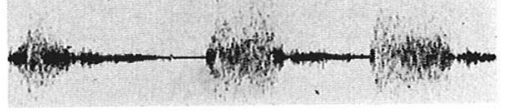

f

図 3 症例 1 a, b 単純軸写像 $\left(90^{\circ}\right)$. 右側の膝盍骨は外側脱臼している.

$\mathrm{c}, \mathrm{d}$ 筋トルク曲線.

$\mathrm{e}, \mathrm{f}$ 表面筋電図

症例 3.I.H., 20 才, 男子. 左側は14才，右側は i5才時にスポーツ外傷により，膝蓋骨の脱臼骨折を 起こし，左側は 2 本の骨釘による骨片の固定後，骨片 の骨吸収が起ったので Tavernier 法を施行した。一
方，右側は最初から Tavernier 法を行なった（図 5 a, b). 右側の筋力は, 伸展力 $84.3 \mathrm{ft}$.-lbs (正常人 20 代の男子の平均 ピークトルク值は $112 \mathrm{ft}$.-1bs）之 正常值に近い值を示しているのに対し，左側は 21.2 


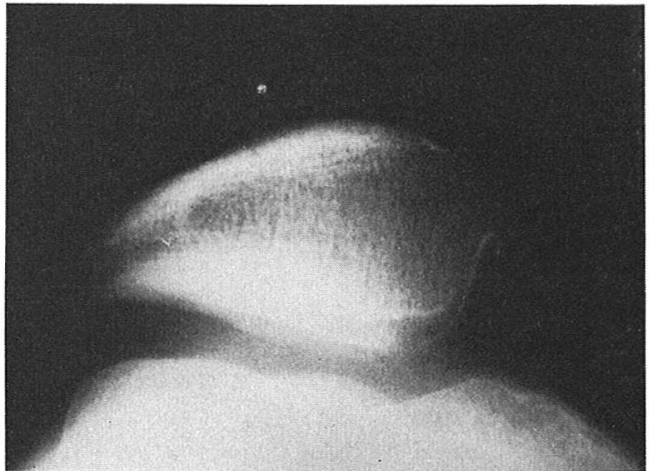

a
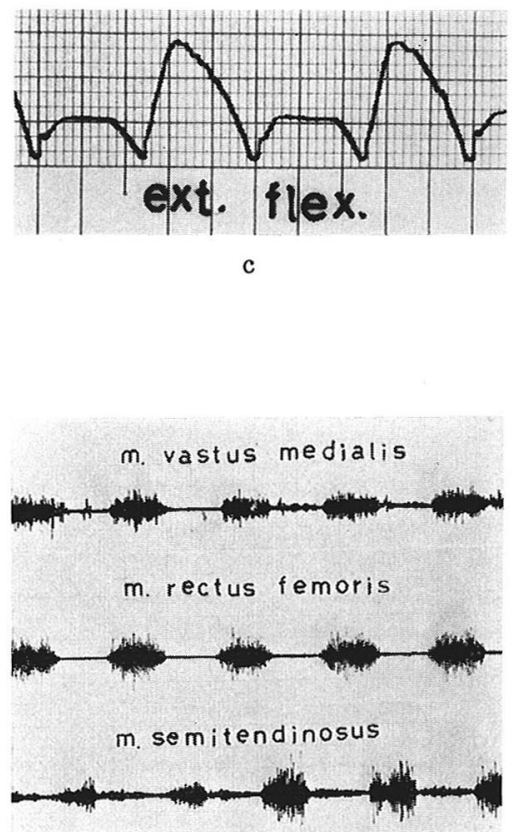

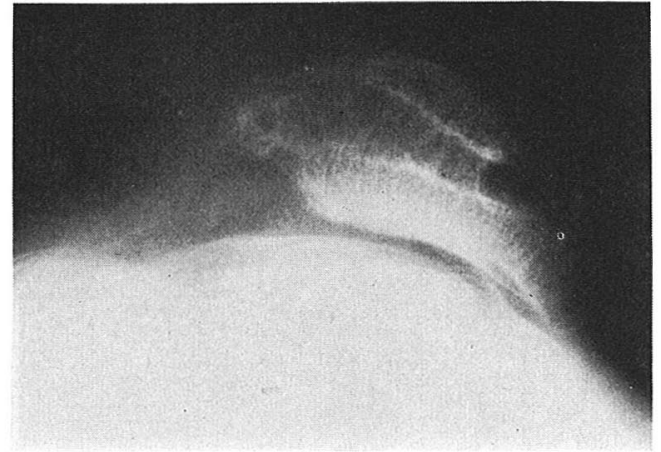

b

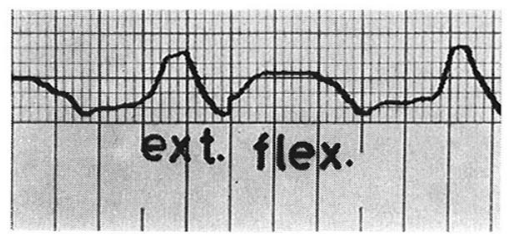

d

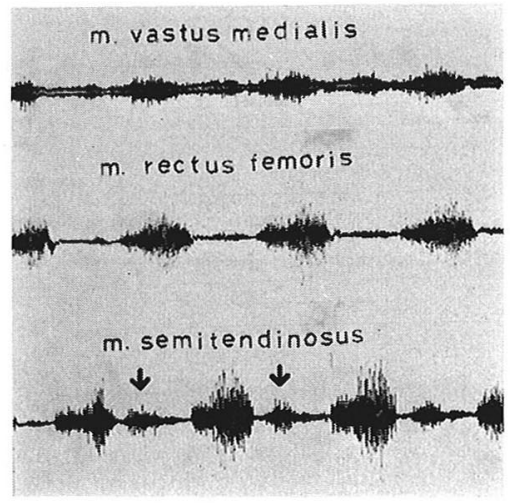

f

図 4 症例 2 a， b 軸写像 $\left(90^{\circ}\right)$. 左側滕蓋骨は脱臼傾向あり.

$\mathrm{c}, \mathrm{d}$ 筋トルク曲線. 左側はトルクカーブが時徵的である.

$\mathrm{e}, \mathrm{f}$ 筋電図. 半腱様筋は膝伸展洔にも収縮がみられる。（矢印）

ft.-lbs で伸展・屈曲力は逆転し, 伸展力の著しい低下 を認めた（図 5 c, d).

症例 4. S.K., 23 才, 女子. 約 10 年前より両膝関 節痛があったが寛解していた，疼痛が増強してきた ため両側膝盍骨㳄骨軟化症の診断で，56 年 7 月 左大 腿骨内顆部切除術を施行した。 術後症状が増悪したた め, 同年 11 月 Maquet 法を施行した.さらに57 年
4月右側に同様の手術を行なった，術後における筋力 增強效果をみてみると, 左側で $70 \%$, 右側で $10 \%$ の 筋力增強を認めた（図 $6 \mathrm{a}-\mathrm{d}$ ).

結 果

1. ピークトルク值

術前および術後の片側例 (10 例) の健・患側の筋 

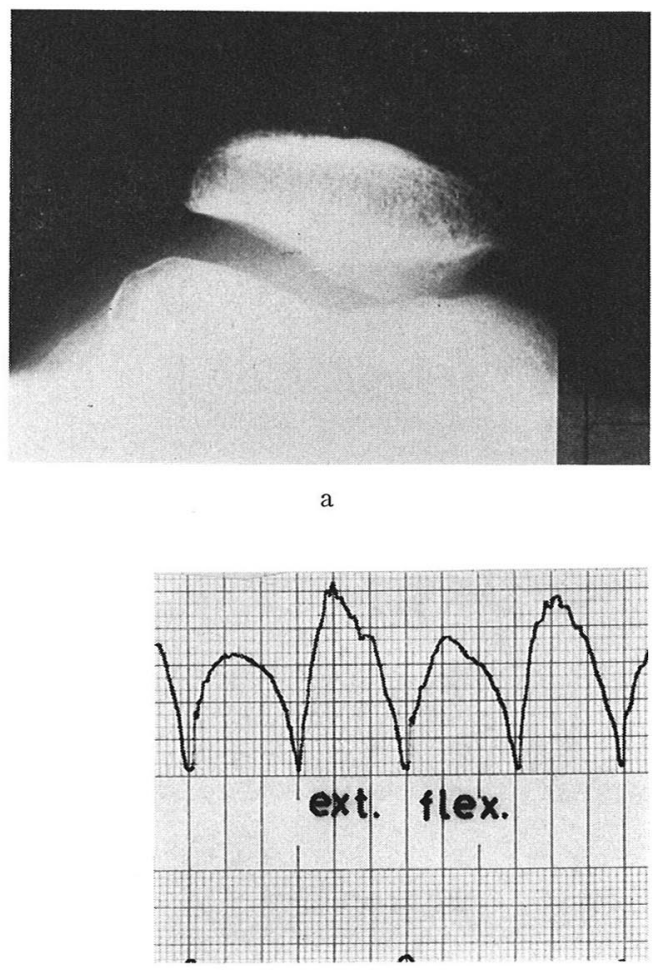

c

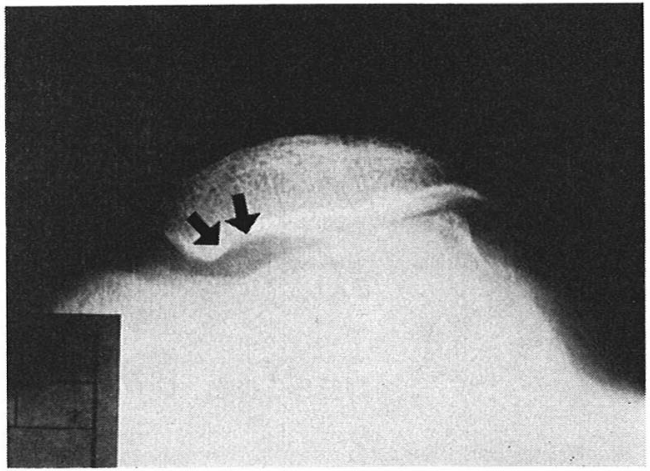

$\mathrm{b}$

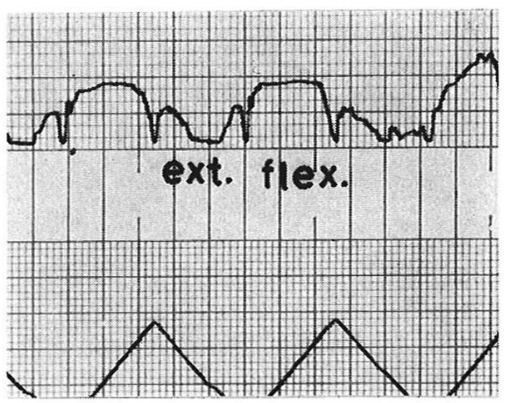

d

図 5 症例 $3 a$, b 軸写像. 左側骨吸収像 (矢印) あり。

$\mathrm{c}, \mathrm{d}$ 筋トルク曲線. 伸展筋力低下が左側で著しい.

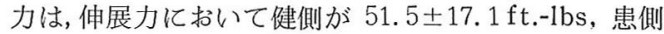
め $34.2 \pm 14.8 \mathrm{ft} .-1 \mathrm{bs}$ であり，屈曲力においては健側 が $27.3 \pm 8.4 \mathrm{ft} .-1 \mathrm{bs}$ ，患側が $22.7 \pm 9.2 \mathrm{ft} .-1 \mathrm{bs}$ であ った．乙の健・患側間の筋力の有意差をみると，伸展 力では危険率 $\mathrm{p}<0.01$ で差を認めたが，届曲力では 有意差を示さなかった. さらに片側性の習慣性膝蓋骨 脱臼例（5 例）では，伸展力のみならず屈曲力におい ても $\mathrm{p}<0.01$ で健側と患側の間に有意差を認めた. 女子の場合のピークトルク值の伸展・屈曲力を正常人 のそれと比較すると, 術後例では手術側のみならず非 手術側の筋力低下が伸展力において，特に著しかった (図 7,8$)$.

2. 最大仕事量の比較

ピークトルク值と同様に, 片側例 10 例の最大仕事 量の平均值は, 伸展力において健側が $53.9 \pm 18.2 \mathrm{ft}$.lbs, 患側が $28.8 \pm 13.0 \mathrm{ft} .-1 \mathrm{bs}$ であり，屈曲力の最

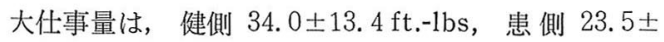

$10 \mathrm{ft} .-\mathrm{lbs}$ であった. 得られた值の腱・患側間の比較 をすると, 伸展力は $\mathrm{p}<0.01$, 属曲力は $\mathrm{p}<0.05$ で 有意差を認めた. この有意差は 5 例の習慣性膝蓋骨脱 臼の場合も同様にみられた。

3. 伸展力之屈曲力の比

健側に対する患側の筋力比（\%) を求めると，片側 例 10 例 では, ピークトルク值が伸展力 $64.2 \pm 19.5$

(\%), 屈曲力 $83.9 \pm 26.3(\%)$ となり, 仕事量では 伸展力 $51.7 \pm 20$ (\%), 屈曲力 $75.5 \pm 38.5$ （\%) で あった。

$$
\text { 考察 }
$$

膝盍骨亜脱臼や膨蓋骨㳄骨㳄化症など膨蓋,骨に関す る疾患の病因や病態さらに治療についての文献が，最 近数多くみられ，乙れらの疾患が究明されつつある4 7). しかしながら，習慣性膝蓋骨脱臼の原因のひとつ とされている内外側広筋の筋力不均衡の実態, あるい 

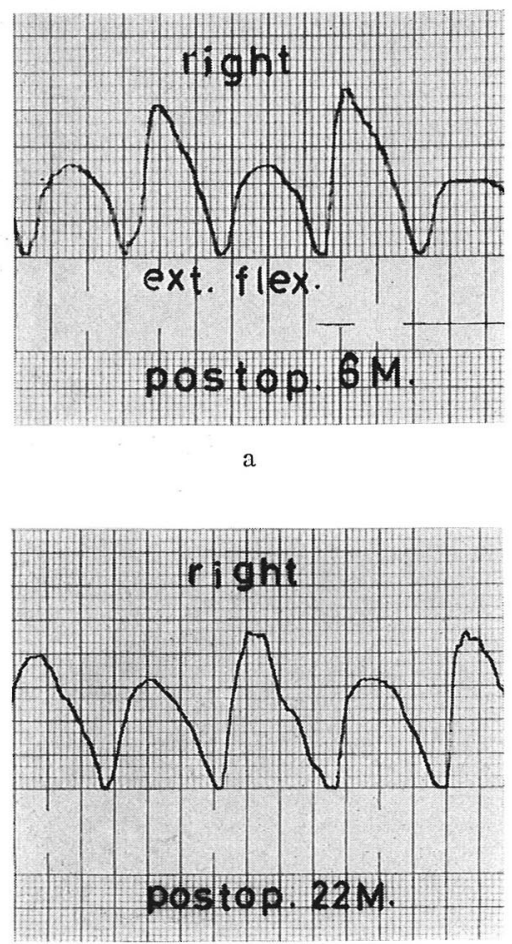

c

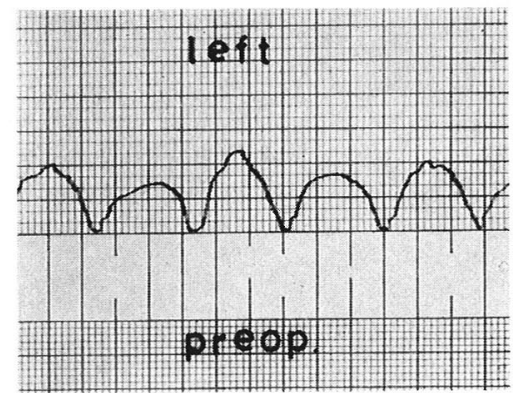

b

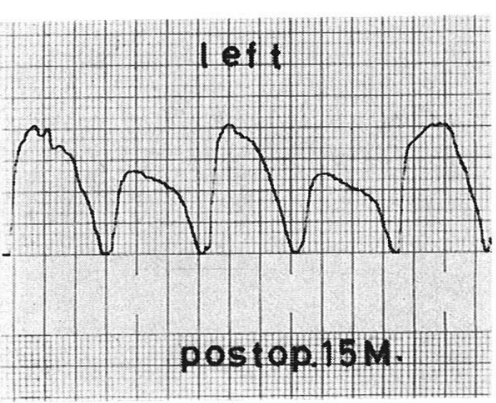

d

図 $6(\mathrm{a}-\mathrm{d})$ 症例 4 筋トルク曲線. 筋力増強が左側で著しい.

PEAK

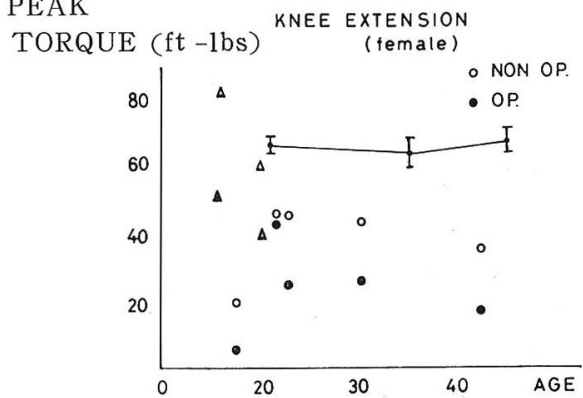

図7正常人との筋力比較（伸展力）

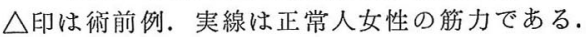

は膝蓋骨軟骨軟化症における Maquet 法によるレバ ーアームの延長効果は，実際にどの程度かなどは解明 されていない225). いずれにしても筋力の定量的測定 は後療法プログラムのひとつの目安となるため重要で あると思われる.

本研究の結果では, ピークトルク值と最大仕事量は

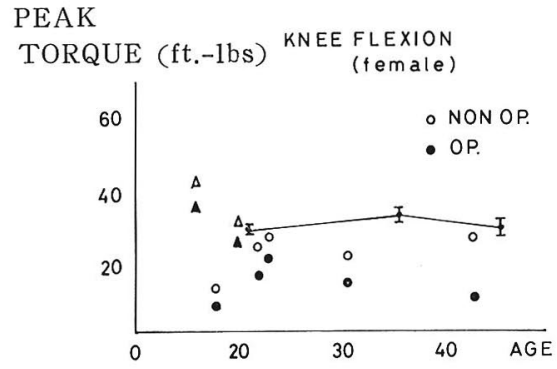

図8 正常人との筋力比較 (屈曲力) $\triangle$ 印は術前例，実線は正常人女性の筋力である。

ともに $\mathrm{p}<0.01$ で伸展力に有意差を認めたが，両側 例を追加しても，患側のみならず健側の伸展筋力の低 下が正常の伸展力に比べて明らかであり，特に術後例 の筋力低下が顕著にみられた. しかし, 術前の M.T. 例では健側の膝蓋骨は亜脱曰位にあかかわらず，筋力 は正常に保たれていた．乙れは本例が創道の選手であ り日頃のトレーニングによるものと考える.

Nicoholas ら (1976) は，6群の疾患群のうち膝 
蓋骨に関する疾患群において, 伸展力は $\mathrm{p}<0.005$, 屈曲力は $\mathrm{p}<0.01$ で対照群と有意差を生じ, 乙の疾 患群が最む伸展力の影響を受けやすやすいとしてい る.これはピークトルク值の比較をしたあのである が, 本研究の結果からも, 筋力の比較は最大仕事量な ぞ筋力持久力を含めた検討も必要と考える.

次に Maquet 効果についてであるが, 対象例のな かで効果のあった例と筋力增強が得られなかった例が みられたが，少なくとも patello-femoral joint の alignment が正常である状態での膝蓋骨腱前方移動 術でなければ, 筋力増強は得られないであろうと推测 する.

また, 筋電図の所見で半腱様筋腱移行術後の移行筋 に特異な筋収縮を認めたが，乙の事実は膝伸展時に， 移行腱の脱臼予防の効果であろうと考える. また, 内 外側広筋の筋収縮を分析する場合, 定性的検討だけで なく，積分計などによる定量的検討が必要となろう.

以上より, 膝蓋骨に関する疾患では, 特に伸展力に 影響が強く出現するため, 日常のトレーニングが筋力 低下を防ぐあのと考え, ランニングや四頭筋訓練を急 らないことが肝要である.

\section{結語}

膝蓋骨疾患10例14関節の膝伸展 ・屈曲力を CybexII で測定し, 正常人の対照群と比較した. また, 表面 筋電計で大腿四頭筋などの筋収縮を検索しその態様を 検討し次の結果を得た.

1) 半腱様筋腱移行術で伸展時に移行腱の筋収縮が みられたが，筋力回復は認められない。

2) 脙蓋骨, 大腿関節の適合が良好な場合, Maquet 法の効果が出ると考えられる.

3）膝蓋骨疾患は伸展力および届曲力ともに筋力低 下がみられる．とくに術後の伸展力低下が著明であっ た.

4）以上の結果から, 膝蓋骨疾患においては術後は 屯ちろん, 術前よりの四頭筋訓練を中心とし筋力増強 訓練が大切である.
文献

1) Campbell, D. E., and Glenn, W.: Rehabilitation of knee flexor and extensor muscle strength in patients with meniscectomies, ligamentous repairs, and chondromalacia. Phys Therapy, 62: 10-15, 1982.

2）片岡 治： いわゆる習慣性膝蓋骨脱臼，臨整 外, 3: 222-231, 1968.

3）川島圭司・他：Cybex-II データ解析法. 理 · 作・療法, 18: 283-284, 1984.

4) 小林 晶: Chondropathia patellae の臨床 像. 臨整外, 14:26-35, 1979.

5) Mapuet, P.: Advancement of tibial tuberosity. Clin Orthop. 115: 225-230, 1976.

6) Nicholas, J. A., Strizak, A. M., and Veras, G.: A study of thigh muscle weakness in different pathological states of lower extremity. Am. J. Sports Med. 4: 241248, 1976.

7) 須津富鶪：Chondromalacia patellae の成因 に関する実験的研究. 日整会誌，55：1535-1553， 1981.

8）上崎典雄 - 他：習慣性膝蓋骨脱曰の治療。臨整 外, 6: 587-590, 1977.

質 問 九州労災病院 井原 秀俊 脛骨結節前方移動した例で筋力が術前より増強した あのがありましたが，それは関節内圧が減少したため に筋力が増強したのでしょうか，それとも疼痛が軽減 したためでしょうか. というのも，水腫などで関節内 圧が上昇すると大腿四頭筋の筋力訓績もしにくいし， 筋力も減少するという文献があるあのですから．ま た, 術後の患者の関節水腫と筋力の関係について調心 られちでしょうか.

\section{解 答 九大理学療法部 豊水 敏宏}

(1) 疼痛の減退が筋力増強を得たと考える. 関節内 死との関連については検討していないが，大腿骨，膝 蓋骨関節の正常な位置関係での脛骨粗面前方移動術が 筋力増強につながると考える.

(2). 関節水腫は存在していなかった. 